\title{
Self Disclosure of Aceh Facebook-Addicted Users
}

\author{
Febri Nurrahmi \\ Department of Communication \\ Faculty of Social and Political Sciences \\ Syiah Kuala University \\ Banda Aceh, Indonesia \\ febri.nurrahmi@unsyiah.ac.id
}

\begin{abstract}
Facebook is the most prominent social media platforms offering various attractive and captivated features. It is common to observe its users become addicted and incessantly spend an excessive amount of their time on this site. Like other addictions, Facebook addiction also has negative consequences on daily lives of its users and it often affects their face-to-face communication. This study aims to investigate the influence of Facebook addiction towards self-disclosure as the key determiner in the interpersonal communication. It used a descriptive quantitative method using a cross-sectional survey of 122 university students selected by quota sampling technique. The data were analyzed with independent sample t-test using the SPSS version 22 software to examine the difference of selfdisclosure between high and low Facebook addicted groups. Findings reveal that the users with high level of Facebook addictions are more likely to have low self-disclosure than those with the low level of Facebook addictions.
\end{abstract}

Keywords - self-disclosure; Facebook; addiction; social media; face-to-face communication

\section{INTRODUCTION}

Facebook is one of the most visited sites after Google and YouTube [1]. According to Facebook reports in the first quarter of 2018, Facebook's daily number of active users around the world now stands at 1.45 billion, while the monthly active users reach 2.2 billion [2]. With users reaching up to 130 million accounts, Indonesia becomes the fourth largest Facebook users in the world [3].

The previous study found that most of active Facebook users are full-time college students [4]. Their tight schedule and academic activities usually motivated them to become dependent on the internet. Hence, they are very potential to experience various problems related to internet usage. According to a survey, 93\% of university students have Facebook accounts and most of them spend 47 minutes per day on Facebook [5].

Regardless of Facebook popularity around the world, Facebook users have strong tendency to get addicted so that they will spend the excessive amount of time to stay on Facebook and lose their self-control over their Facebook use [6]. The study of the level of social media addiction also showed that Facebook users are more likely to get addicted than users of other social media [7]. There are six dimensions to determine whether the individual has been classified as
Facebook addicts; salience (e.g., spending a lot of time thinking about Facebook), mood modification (e.g., using Facebook to improve mood), withdrawal symptoms (e.g., feeling restless and messed up without using Facebook), tolerance (e.g., using Facebook for a long time), conflict (e.g., negatively impact on personal life), and relapse (e.g., feeling obliged to use Facebook continuously) [8].

This phenomenon can be best explained by dependency media theory. This theory assumes that the more one relies on his needs to be fulfilled by the media use, the more critical the role of the media in the person's life [9]. According to Malvin Defleur and Sandra Ball-Rokeach [10], mass media have power towards their audiences due to the dependence of the audience on the mass media content. Audiences have created a routine of various media usage, and can quickly adjust their use to meet their needs [9]. In modern society, people are increasingly dependent on the media to understand the social world, find fantasies, and escape from reality [10]. In this regards, most Facebook users get addicted as they cannot be separated from social media in obtaining information or entertainment.

Internet addicts, including Facebook, have a strong tendency to conduct solitary activities and restrict their social activities [11]. Nearly $20 \%$ of Internet users are involved with the self-ignorance, checking and clicking behavior continuously, socially isolated and avoiding others, loss of productivity, depression, marriage problems, sex addiction, gambling, Internet abuse at work, and study failures [12]. Individuals who are not able to express themselves in the real world are nicely inclined to form coping in cyberspace, especially in social media like Facebook, to get the emotional support they do not get in the real world. This is in line with the statement that the internet provides its convenience leading to addiction because it is anonymous and not face-to-face communication [8]. Internet users who avoided face-to-face interaction or found face-to-face interaction less rewarding and avoided it using the Internet to fulfill their interpersonal needs [13]. Further, the study showed that people who are willing to avoid face-to-face communication would use Facebook to spend their time [5]. It is also suggested that people with difficulties in face-to-face communication will get involved in online relationships [14].

In other words, Facebook addiction is implicated to selfdisclosure in real life since it is a crucial determiner in the 
development of the interpersonal relationship [15]. Revealing information about himself to another is seen as the measure of an ideal relationship [16]. Interpersonal communication quality is adequately measured from the level of self-disclosure that occurs in the communication [17]. A person who is capable of expressing himself tends to be more competent, reliable, more able to be positive, trust in others, more objective, and open, while a person who is unable to perform self-disclosure will also be incapable of adjusting, less confident, fears, anxious, feeling inferior, and closed [18].

Although the use of excessive time on Facebook also influence face-to-face communication, only a little attention has been paid to this topic. Many studies on Facebook addiction aims to describe the level of Facebook addiction [7], [19], [20], their implications on psychological effects of users, such as life satisfaction [21], narcissism and stress [22]. Research on social media in Indonesia has previously focused more on self-disclosure in cyberspace [23], [24]. One of the previous similar studies in Indonesia regarding the influence of WhatsApp on introvert behavior among university students revealed the relationship between both investigated variables [25]. Therefore, this study aims to describe the influence of Facebook addiction on the level of self-disclosure in face-toface communication among university students.

\section{METHOD}

\section{A. Sample}

This study conducted a survey with 122 university students at the largest university in Aceh, Syiah Kuala University. To ensure each faculty proportionately represented, the respondents were purposively selected from all faculties using quota sampling technique. The participation was voluntary and only the students who have Facebook accounts were preferred. The survey used the questionnaire measuring the respondents' demographics, the level of Facebook addiction, and the level of self-disclosure. $\square$

\section{B. Measurement}

For demographic questions, the respondents were asked to identify their gender, give their age, and indicate how long they had Facebook accounts. The questions were intended to provide the personal background of the respondents in this study.

The level of Facebook addiction was measured by six dimensions; salience, mood modification, withdrawal symptoms, tolerance, conflict, and relapse, each contained three items, 18 items in total. The items were developed from past internet addiction studies [8]. However, as the study is not specifically aimed at Facebook, the items were redefined so that they would be more appropriate. The items were measured with a 4-point Likert scale (1 = strongly disagree, 4 = strongly agree). The higher score indicated the higher level of Facebook addiction. All items were validated using Product Moment Pearson Correlation and its results showed that 18 items of the Facebook addiction had p-values less than 0.05, meaning that all item were valid. The reliability test with Cronbach's Alpha yielded reliability coefficient of 0.863 , indicating that the instrument is reliable.

The level of self-disclosure was assembled from the past study on self-disclosure [18]. An 18-item self-disclosure scale reflected nine indicators; expressing self accurately, adjusting, confident, competent, reliable, being positive, believing others, more objective, and open. A 4-point Likert scale was devised in rating 18 self -disclosure items, ranging from 1 (strongly disagree) to 4 (strongly agree). Higher scores indicated that the respondents are good at expressing themselves to others in interpersonal encounters. All items were valid as the p-values for 18 items of self-disclosure were less than 0.05 . The result of the reliability test showed 0.795 for Cronbach's Alpha coefficient, thus the items are reliable.

\section{Analysis}

All statistical analyses in this study were conducted using the Statistical Product and Service Solution (SPSS) 22 software. After the descriptive analyses of demographics, Facebook addiction variable and self-disclosure variable, the respondents were classified into two groups based on their Facebook addition score. The total score for the Facebook addiction instrument ranged from 18 to 72 . The respondents who had the score less than 45 were classified the in the lowaddicted group, while they with the score more than 45 were categorized into the high-addicted group. Next, independent sample t-test was employed to compare self-disclosure score between both groups.

\section{FINDING AND DISCUSSION}

\section{A. Demographics}

TABLE I. RESPONDENTS’ GENDER

\begin{tabular}{|l|l|c|c|}
\hline No & \multicolumn{1}{|c|}{ Gender } & Frequency & Percentage \\
\hline 1 & Men & 76 & 62.3 \\
\hline 2 & Women & 46 & 37.7 \\
\hline
\end{tabular}

In terms of gender, the majority of the respondents were men with $62.3 \%$, while women were $37.7 \%$.

TABLE II. RESPONDENTS’ AGE

\begin{tabular}{|l|l|c|c|}
\hline No & Age & Frequency & Percentage \\
\hline 1 & 18 years old & 4 & 3.3 \\
\hline 2 & 19 years old & 15 & 12.3 \\
\hline 3 & 20 years old & 20 & 16.4 \\
\hline 4 & 21 years old & 32 & 26.2 \\
\hline 5 & 22 years old & 42 & 34.4 \\
\hline 6 & 23 years old & 9 & 7.4 \\
\hline
\end{tabular}

The respondents' age was ranged from 18 to 23 years old. Most of the respondents were 22 years old with $34.4 \%$, followed by 21 years old (26.2\%), 20 years old (16.4\%), 19 
years old (12.3\%), 23 years old (7.4\%), and 18 years old (3.3\%).

TABLE III. RESPONDENTS' LENGTH OF TIME OF FACEBOOK

\begin{tabular}{|l|l|c|c|}
\hline \multicolumn{1}{|c|}{ No } & \multicolumn{1}{|c|}{ Length of Time } & Frequency & Percentage \\
\hline 1 & < 1 year & 2 & 1.6 \\
\hline 2 & 1-2 year & 14 & 11.5 \\
\hline 3 & 3-4 year & 54 & 44.3 \\
\hline 4 & >5 year & 52 & 42.6 \\
\hline
\end{tabular}

Almost half of the respondents have used Facebook since 3-4 year (44.3\%), followed by Facebook users since more than 5 years (42.6\%), $1-2$ years $(11.5 \%)$, and less than 1 year (1.6\%).

\section{B. Level of Facebook Addiction}

TABLE IV. RESPONDENTS' LEVEL OF FACEBOOK ADDICTION $\square$

\begin{tabular}{|l|l|c|c|}
\hline No & Level of Addiction & Frequency & Percentage \\
\hline 1 & Low & 28 & 23 \\
\hline 2 & High & 94 & 77 \\
\hline
\end{tabular}

The most of respondents (77\%) had the high level of Facebook addiction, while other 23\% of respondents were considered as low Facebook addicts. On average, their level of Facebook addiction is high.

\section{Level of Self-Disclosure}

TABLE V. RESPONDENTS' LEVEL OF SELF-DISCLOSURE

\begin{tabular}{|l|l|c|c|}
\hline No & Level of Addiction & Frequency & Percentage \\
\hline 1 & Low & 51 & 41.8 \\
\hline 2 & High & 71 & 58.2 \\
\hline
\end{tabular}

$58.2 \%$ respondents showed the high level of self-disclosure. Meanwhile, the low level of self-disclosure was found in $41.8 \%$ of the respondents.

\section{Independent Sample T-Test}

TABLE VI. SELF-DISCLOSURE DIFFERENCES

\begin{tabular}{|l|l|c|c|}
\hline \multirow{2}{*}{ No } & \multicolumn{3}{|c|}{ Independent sample t-test } \\
\cline { 2 - 3 } & \multicolumn{1}{|c|}{ Groups } & Mean & p-value \\
\hline 1 & Low Facebook-Addicted & 51 & \multirow{2}{*}{0.000} \\
\hline 2 & High Facebook-Addicted & 45 & \\
\hline
\end{tabular}

According to the result of independent sample t-test, it is known that the p-value of is 0,000 , or smaller than 0.05 . Thus, it can be concluded that there is a significant difference of selfdisclosure between high and low Facebook-addicted groups. Based on the mean score of self-disclosure, low Facebook- addicted groups have higher mean score than low Facebookaddicted groups. The self-disclosure level of less Facebook addicts is high, while the self-disclosure level of more Facebook addicts is low.

The findings implied that Facebook causes face-to-face interaction tends to decline. Many people prefer to use this social networking site as it offers anonymity and mediated communication so that users do not need to meet in person to disclose themselves. Therefore, they become more comfortable sitting for hours with their smartphone, spending time on Facebook. This causes the most active Facebook users to become socially ignorant.

The findings are consistent with results of the previous study on the relationship between social media addiction and self-disclosure in direct communication [25]. It is found that that university students feel more comfortable communicating through WhatsApp because they can disclose themselves comfortably that cannot be experienced in their face-to-face communication [25].

Referring to the descriptive results of Facebook addition level, it is known that the majority of the respondents (77\%) had the high level of Facebook addiction. This finding also confirmed the past study college students are prone to be addicted to Facebook [4]. It may be explained by seeing demographic data on the length of Facebook use. Most of the respondents used Facebook for more than three years. Therefore, it could be assumed that their dependence on Facebook is affected by their length of time using Facebook. It supports media dependency theory that media will have an influence on a person's life if the media has been part of his daily life [9]. In this regards, when someone has Facebook for an extended period of time, Facebook is likely to be his routine and has greater chance to influence him.

Another of the descriptive result self-disclosure illustrated that the degree of self-disclosure was relatively high. The explanations may be that they self-disclose in real life as they do online [5]. Therefore, even though they addict to Facebook, they use Facebook to self-disclose and form the online relationship. Thus future studies should take into account the level of self-disclosure on Facebook.

\section{CONCLUSION}

Based on the results of the independent sample t-test, it can be concluded that there is a significant difference in selfdisclosure level between low and high-addicted Facebook groups of the college students in Aceh (p-value $<0.05$ ). The results implied that the two Facebook-addicted groups differed in their level of self-disclosure. The average score of selfdisclosure for the low-addicted group was higher than that of the high-addicted group. The self-disclosure level in the highaddicted group is low, and vice versa. In other words, the dependency level on Facebook will affect the degree of selfdisclosure in face-to-face encounters. 


\section{REFERENCES}

[1] Alexa, “The top 500 sites on the web.," Alexa.com, 2018. [Online]. Available: https://www.alexa.com/topsites.

[2] F. K. Bohang, “Triwulan Pertama 2018, Facebook Raup Rp 166 Triliun [First Quarterly of 2018, Facebook Scoops up Rp166 trillion]," Kompas.com, 2018. [Online]. Available: https://tekno.kompas.com/read/2018/05/02/06520567/triwulan-pertama2018-facebook-raup-rp-166-triliun.

[3] R. C. Septania, "Indonesia, Pengguna Facebook Terbanyak ke-4 di Dunia [Indonesia, world's $4^{\text {th }}$ largest Facebook users],” 2018. [Online]. Available:

https:/tekno.kompas.com/read/2018/03/02/08181617/indonesiapengguna-facebook-terbanyak-ke-4-di-dunia.

[4] K. J. Anderson, "Internet Use Among College Students: An Exploratory Study,” J. Am. Coll. Heal., vol. 50, no. 1, pp. 21-6, 2001.

[5] P. Sheldon, "The Relationship Between Unwillingness To Communicate And Student's Facebook Use,” J. Media Psychol., vol. 20, no. 2, pp. 6775, 2008.

[6] Y. Syukur, Facebook: Sebelah Surga dan Sebelah Neraka [Facebook: One Side Heaven, Other Side Hell]. Yogyakarta: Diva Press, 2009.

[7] M. Gazi, M. Cetin, and C. Cakı, "The research of the level of social media addiction of university students,” Int. J. Soc. Sci. Educ. Res. 3(2), 549-559., vol. 3, no. 2, pp. 549-559, 2017.

[8] M. D. Griffiths, "Internet Addiction-Time To Be Taken Seriously?," Addict. Res., vol. 8, pp. 413-418, 2000.

[9] S. J. Baran, Pengantar Komunikasi Massa: Literasi Media dan Budaya [Mass Communication Introduction: Media dan Culture Literation]. Jakarta: Salemba -Humanika., 2010.

[10] Morissan., Teori Komunikasi Individu Hingga Massa [Theories of Individual to Mass Communication]. Jakarta: PT. Kencana Prenada Media Group, 2013.

[11] K. S. Young, "Internet Addiction: The Emergence of a New Clinical Disorder,” CyberPsychology Behav., vol. 1, no. 3, 1998.

[12] H. Elia, "Kecanduan Internet dan Prinsip-Prinsip Untuk Menolong Pecandu Internet [Internet Addiction and Principals to Help Internet Addict],” J. Teol. dan Pelayanan, vol. 10, no. 2, pp. 285-299, 2009.

[13] A. Papacharissi, Z., \& Rubin, "Predictors of internet use,” J. Broadcast. Electron. Media, vol. 44, pp. 75-196, 2000.
[14] C. C. Ward and T. J. G. Tracey, "Relation of shyness with aspects of online relationship involvement,” J. Soc. Pers. Relat., vol. 21, pp. 611623, 2004.

[15] T. West and L. H. Turner, Introducing Communication Theory: Analysis and Application. New York: McGraw Hill, 2009.

[16] B. Bungin, Sosiologi Komunikasi: Teori, Paradigma, dan Diskursus Teknologi Komunikasi di Masyarakat [Communication Sociology: Theories, Paradigms, and Discourses]. Jakarta: Kencana, 2006.

[17] D. Sendjaja, Teori Komunikasi [Communication Theory]. Jakarta: Pusat Penerbitan Universitas, 2002.

[18] M. B. Gainau, "Keterbukaan Diri (Self Disclosure) Siswa dalam Perspektif Budaya dan Implikasinya Bagi Konseling [Student's SelfDisclosure in Cultural Perspective and its Implications for Counseling]," J. Ilm. Widyawarta, vol. 33, no. 1, pp. 1-17, 2009.

[19] O. F. Alabi, “A survey of Facebook Addiction Level among Selected Nigerian University Undergraduates,” New Media Mass Commun., vol. 10, pp. 70-80, 2013.

[20] A. Kirik, A. Arslan, A. Çetinkaya, and M. Gül, “A Quantitative Research on the Level of Social Media Addiction among Young People in Turkey,” Int. J. Sci. Cult. Sport, vol. 3, no. 3, pp. 108-122, 2015.

[21] C. Sahin, “The Predictive Level of Social Media Addiction for Life Satisfaction: A Study on University Students,” Turkish Online J. Educ. Technol. - TOJET, vol. 16, no. 4, pp. 120-125, 2017.

[22] J. Brailovskala and J. Margraf, "Facebook Addiction Disorder (FAD) among German Students-A longitudinal approach,” PLoS One, vol. 12, no. 12, pp. 1-15, 2017.

[23] W. Suma, "Webblog dan Tingkat Keterbukaan Diri [Webblog and SelfDisclosure Level]," University of North Sumatra.

[24] S. M. Pulungan, "Keterbukan Diri Remaja di Sosial Media Twitter (Studi Pada Siswa SMA Negeri 3 Banda Aceh) [Adolescent's SelfDisclosure on the Social Media of Twitter (Study on the Students of State Senior High School 3 Banda Aceh)],” Syiah Kuala University, 2014.

[25] H. F. Arifin, "WhatsApp terhadap Perilaku Tertutup Mahasiswa (Survey Pada Mahasiswa Ilmu Komunikasi FISHUM Universitas Islam Negeri Sunan Kalijaga Yogyakarta Angkatan 2014) [WhatsApp towards Student's Closed Behavior (Survey on the Students of Communication Science, FISIHUM, State Islamic University of Sunan Kalijaga Yogyakarta)]," State Islamic University of Sunan Kalijaga Yogyakarta, 2015 